\title{
Re-Evaluasi Perencanaan Pengembangan Kota Baru Berdasarkan Informasi Geologi Teknik di Walini, Kecamatan Cikalong Wetan, Kabupaten Bandung Barat, Provinsi Jawa Barat
}

\author{
Wahdatul Khasanah $^{1 *}$, Najib Najib ${ }^{1}$, Taufiq Wira Buana ${ }^{2}$ \\ ${ }^{1}$ Departemen Teknik Geologi, Fakultas Teknik, Universitas Diponegoro, Semarang \\ ${ }^{2}$ Pusat Sumber Daya Air Tanah dan Geologi Tata Lingkungan, Badan Geologi, Bandung
}

\begin{abstract}
SARI
Rencana pengembangan kota baru akan dilakukan di Walini, Kecamatan Cikalong Wetan, Kabupaten Bandung Barat. Penelitian ini dilakukan untuk menyediakan informasi geologi, geologi teknik dan melakukan re-evaluasi lokasi pengembangan kota baru berdasarkan peta kemampuan geologi teknik. Metode penelitian yang dilakukan adalah dengan penyelidikan di lapangan meliputi sifat fisik dan keteknikan tanah/ batuan, kondisi morfologi, struktur geologi dan kedalaman muka air tanah, kemudian mengumpulkan peta bencana geologi dan peta tutupan lahan. Penyusunan peta kemampuan geologi teknik dilakukan dengan pembobotan dan overlay peta kebencanaan geologi yang meliputi peta kerentanan gerakan tanah, peta kerentanan gempa bumi, peta zona rawan letusan gunung api dan peta kerentanan banjir. Morfologi di lokasi penelitian terdiri dari bentuk lahan vulkanik bergelombang landai (lereng $3^{\circ}-9^{\circ}$ ) dan perbukitan struktural terjal (lereng $17^{\circ}-27^{\circ}$ ). Struktur geologi yang dijumpai adalah kekar dan indikasi lipatan. Satuan geologi teknik terdiri dari perselingan batupasir-batulempung, breksi laharik, batupasir kerikilan, dan lanau lempungan. Kedalaman muka air tanah pada lokasi penelitian berkisar antara $5 \mathrm{~m}-20 \mathrm{~m}$. Zona kemampuan geologi teknik pada lokasi penelitian terbagi menjadi zona kemampuan geologi teknik sangat rendah, zona kemampuan geologi teknik rendah, zona kemampuan geologi teknik menengah, dan zona kemampuan geologi teknik tinggi.
\end{abstract}

Kata Kunci: Bandung Barat; Kemampuan Geologi Teknik; Pengembangan; Perencanaan; Walini.

\begin{abstract}
Development plans for new cities will be held in the Walini area, Cikalong Wetan District, West Bandung Regency. The purpose of this study is to provide geological information, engineering geology and re-evaluate the development location a new city based on a map of engineering geology capabilities. The research methode used is collected the physical properties in field includes soil / engineering properties, geomorphological conditions, geological structure and depth of groundwater level, then collected maps of geological disaster and landuse maps. The engineening capability map is carried out by weighting and overlaying vulnerability map of soil movements, earthquake vulnerability maps, volcanic hazard zones and flood vulnerability maps. Based on morphological conditions, the study location consist of volcanic landforms $\left(3^{\circ}-9^{\circ}\right.$ slope $)$ and steep structural hills $\left(17^{\circ}-27^{\circ}\right.$ slope $)$. The identified geological structures in the study location are joint and indication of folds. The engineering geological unit of the study location is divided into intercession of sandstone-claystone, breccia, gravel sandstone and clay silt units. The depth of the groundwater level in the study location ranges from $5 \mathrm{~m}$ $-20 \mathrm{~m}$. The zone of engineering geology capability at the study location consists of very low, low, medium and high geological engineering capabilities zones.
\end{abstract}

Keyword: West Bandung; Geological Engineering Capability; Development; Planning; Walini.

\section{PENDAHULUAN}

Proyek pembangunan Kereta Api Cepat JakartaBandung merupakan salah satu proyek yang dirancang oleh Pemerintah Pusat untuk membangun konektivitas antar kota dan pembangunan wilayah. Pada pembangunan proyek tersebut pemerintah bekerjasama dengan PT. Kereta Cepat Indonesia China (KCIC). Kereta Api Cepat Jakarta-Bandung rencananya akan menghubungkan 4 stasiun, yaitu Kota Administrasi Jakarta Timur (Halim), Kabupaten Karawang, Kabupaten Bandung Barat (Walini), 


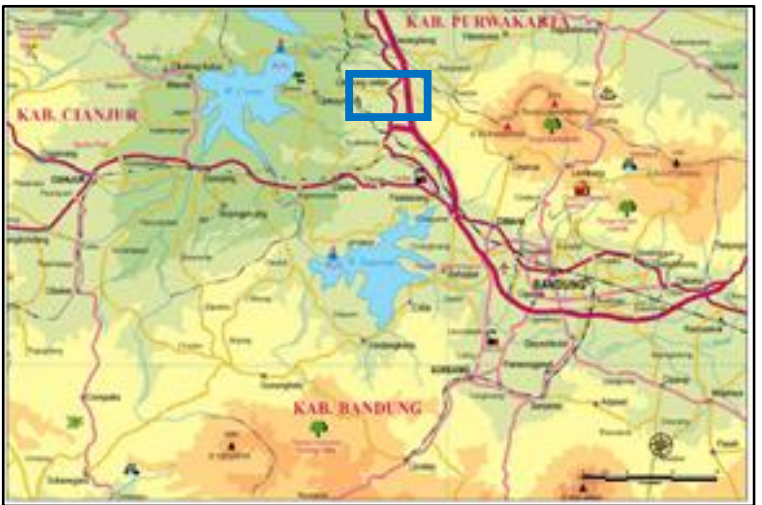

Gambar 1. Lokasi pemetaan di Daerah Walini, Kecamatan Cikalong Wetan (BAKOSURTANAL, 2007). Kotak biru menunjukkan lokasi penelitian.

dan Kabupaten Bandung (Tegalluar). Dalam hal ini Walini akan dikembangkan menjadi kota untuk menggerakkan perekonomian di kawasan stasiun dan sekitarnya oleh PT. KCIC. Penelitian dilakukan pada sebagian area yang akan dikembangkan menjadi kota baru Walini. Secara administratif lokasi penelitian berada di Kecamatan Cikalong Wetan, Kabupaten Bandung Barat, Provinsi Jawa Barat (Gambar 1).

Analisis kesesuaian lahan untuk pemukiman di Kabupaten Bandung dan Bandung Barat oleh Masri (2012) menghasilkan peta kesesuaian lahan pemukiman dengan skala 1:100.000 dan lokasi penelitian termasuk daerah dengan kesesuaian lahan sedang-buruk.

Penelitian ini bertujuan untuk mengetahui kondisi geologi, sifat fisik dan keteknikan tanah atau batuan, serta parameter-parameter kebencanaan geologi sehingga dapat disusun Peta Zonasi Kemampuan Geologi Teknik di daerah penelitian sehingga dapat digunakan untuk melakukan re-evaluasi terhadap penggunaan lahan sebagai kota baru yang telah direncanakan oleh PT. KCIC dan dapat dijadikan sebagai pertimbangan untuk meminimalisir kesalahan dalam rencana pengembangan kota baru di Walini.

Menurut The Unesco Press (1976) peta geologi teknik adalah sebuah peta yang menyediakan informasi secara umum dari kondisi geologi yang penting dalam perencanaan penggunaan lahan, desain konstruksi dan pemeliharaan. Informasi tersebut diperlukan untuk menilai kelayakan penggunaan lahan yang diusulkan untuk rekayasa dan membantu dalam pemilihan jenis dan metode konstruksi yang tepat.
Peta kemampuan geologi teknik merupakan suatu peta yang menggambarkan informasi terkait tingkatan kemampuan geologi teknik di suatu daerah untuk dikembangkan dengan perkiraan biaya yang lebih ekonomis atau biaya tinggi serta memperkirakan rekayasa keteknikan jika diperlukan pada daerah tersebut.

Menurut Utami dan Sutarjan (2002) parameter yang digunakan pada penyusunan peta kemampuan geologi teknik meliputi kemiringan lereng, daya dukung tanah, bahaya aspek geologi, kemudahan penggalian tanah di lapangan dan kedalaman muka air tanah. Kelas kemampuan geologi teknik diperoleh dengan menggunakan rumus (Khadiyanto, 2005):

$$
\mathrm{I}=\mathrm{R} / \mathrm{N}
$$

Keterangan I = lebar interval (skor maksimum - skor minimum)

$\mathrm{R}=$ jarak interval

$\mathrm{N}=$ jumlah interval

Penyusunan peta kemampuan geologi teknik dilakukan dengan menggunakan Sistem Informasi Geografis (SIG). SIG merupakan sistem informasi yang mampu mengelola data yang memiliki informasi spasial serta mampu memberikan informasi yang mendekati dunia nyata, memprediksi suatu hasil dan menampilkan data bereferensi geografis. Keunggulan dari SIG salah satunya adalah melakukan tumpang susun (overlay) data-data dari suatu wilayah, sehingga metode tersebut dapat digunakan untuk menghasilkan informasi baru seperti pada penyusunan peta kemampuan geologi teknik.

\section{Geomorfologi Regional}

Walini merupakan salah satu daerah yang berada di Kecamatan Cikalong Wetan, Kabupaten Bandung Barat, Provinsi Jawa Barat. Secara fisiografis daerah Jawa Barat terbagi menjadi enam zona yaitu Zona Dataran Aluvial Jawa Barat Utara, Zona Antiklinorium Bogor, Zona Gunung Api Kuarter, Zona Depresi Tengah Jawa Barat, Kubah dan Pegunungan pada Zona Depresi Tengah, dan Pegunungan Selatan (van Bemmelen, 1949). Berdasarkan peta fisiografis daerah Jawa Barat lokasi penelitian termasuk pada Zona Bogor. Menurut Martodjojo (1984), Cekungan Bogor merupakan cekungan depan busur magmatik yang berubah menjadi cekungan belakang busur magmatik pada kala Miosen 
Awal-Pliosen, pada Plio Plistosen sebagian Cekungan Bogor terangkat menjadi dataran dan merupakan jalur magmatis aktivitas vulkanisme sehingga menghasilkan endapan-endapan.

\section{Stratigrafi}

Berdasarkan Peta Geologi Lembar Cianjur (Sudjatmiko, 1972) daerah penelitian tersusun atas Formasi Cantayan Anggota Batupasir dan Hasil Gunung Api Tua.

a. Formasi Cantayan Anggota Batupasir terdiri dari batupasir kotor berlapis baik, serpih pasiran, lempung serpihan, breksi laut dan konglomerat.

b. Hasil Gunung Api Tua tersusun atas breksi, lahar, lava. breksi gunung api, breksi aliran, endapan lahar dan lava menunjukkan kekar tiang, susunannya andesit dan basalt.

\section{Struktur Geologi}

Pulonggono dan Martodjojo (1994) menyimpulkan bahwa di Pulau Jawa terdapat tiga arah kelurusan dengan arah struktur dominan yaitu:

a. Pola Meratus yang berarah timurlautbaratdaya (NE-SW), diwakili oleh Sesar Cimandiri dan Sesar Naik Rajamandala di Jawa Barat. Menurut Martodjojo (1994) Pola Meratus dihasilkan oleh tektonik kompresi berumur Kapur Akhir - Eosen Awal.

b. Pola Sunda yang berarah utara - selatan $(\mathrm{N}-$ S), diwakili oleh Sesar Cidurian dan sesarsesar yang berada di daerah Leuwiliang (Martodjojo, 1984), di lepas pantai utara Jawa Barat pola ini merupakan pola yang paling dominan. Pola Sunda berumur Eosen Akhir - Oligosen Akhir.

c. Pola Jawa yang berarah barat - timur (E-W), diwakili oleh sesar-sesar naik seperti Baribis serta sesar-sesar naik di dalam Zona Bogor (van Bemmelen, 1949).

\section{METODOLOGI}

Metode yang digunakan pada penelitian ini adalah metode survei deskriptif yaitu melakukan pengamatan secara langsung di lokasi penelitian meliputi kondisi geomorfologi, sifat fisik dan keteknikan tanah batuan/ tanah, struktur geologi dan kedalaman muka air tanah. Selanjutnya mengompilasikan data sekunder berupa peta kerentanan gerakan tanah, peta kegempaan, peta rawan bencana gunung api, dan peta kerentanan banjir.

Peta gromorfologi dibuat berdasarkan klasifikasi Nichols dan Edmundson (1975), yang membagi satuan relief berdasarkan persen kemiringan lereng (Tabel 1), kemudian menganalisis proses geologi yang membentuk morfologinya. Peta geologi teknik disusun berdasarkan sifat fisik dan keteknikan tanah atau batuan yang diperoleh dari hasil Unconfined Compression Test (UCS) dan pengukuran Rock Mass Rating (RMR) terhadap sampel bor terpilih (lokasi titik bor dapat dilihat pada Gambar 3). Pengukuran kedalaman muka air tanah dilakukan pada 8 sumur gali milik penduduk (Gambar 3) dan 2 sumur pemboran untuk dapat membuat peta kedalaman muka air tanah. Peta kerentanan gerakan tanah (PVMBG, 2008a), peta kerentanan letusan gunungapi (PVMBG, 2008b), peta kerentanan banjir, menggunakan peta yang dikeluarkan oleh Pusat Vulkanologi dan Mitigasi Bencana Geologi, sedangkan peta kerentanan gempa bumi diambil dari SNI (2017).

Re-evaluasi pengembangan kota baru berdasarkan pada peta kemampuan geologi teknik, yang dibuat dengan melakukan metode tumpang susun (overlay) peta tematik. Peta-peta tersebut telah dinilai dan diberi bobot dengan Sistem Informasi Geografis (GIS) berdasarkan pembobotan Utami dan Sutarjan (2000). Kisaran nilai adalah $1-4$, semakin tinggi nilai berarti semakin tinggi tingkat peranannya terhadap kemampuan lahan. Dalam penilaian tingkat kemampuan geologi teknik ini, nilai 4 menunjukkan parameter tersebut memiliki kemampuan yang tinggi, nilai 3 untuk menengah, 2 untuk rendah dan 1 untuk sangat rendah. Pembobotan dilakukan untuk menunjukkan kepentingan terhadap kemampuan lahan. Bobot 5 berarti menunjukkan kepentingan sangat tinggi, bobot 4 kepentingan tinggi, bobot 3 kepentingan menengah, 2 kepentingan rendah, dan 1 kepentingan sangat rendah.

\section{HASIL}

\section{Kondisi Morfologi Lokasi Penelitian}

Berdasarkan hasil pengamatan di lapangan morfologi pada lokasi penelitian terbagi menjadi 2 satuan yaitu bentuklahan perbukitan struktural terjal dan perbukitan vulkanik bergelombang landai (Gambar 2). Satuan Bentuklahan Perbukit- 


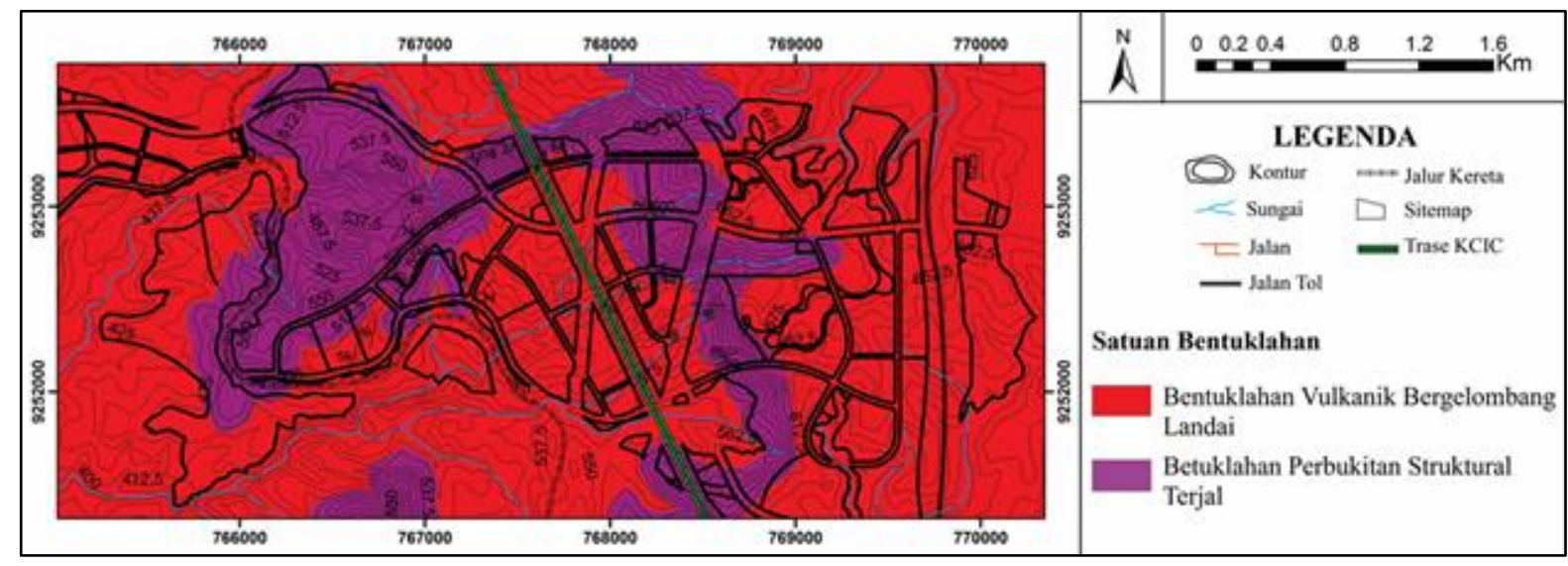

Gambar 2. Peta geomorfologi daerah Walini dan sekitarnya.

Tabel 1. Klasifikasi kemiringan lereng (Nichols dan Edmundson, 1975)

\begin{tabular}{lcc}
$\begin{array}{c}\text { Satuan } \\
\text { relief }\end{array}$ & $\begin{array}{c}\text { Kemiringan } \\
\text { Lereng }(\%)\end{array}$ & $\begin{array}{c}\text { Kemiringan } \\
\text { Lereng }\left({ }^{\mathbf{*}}\right)\end{array}$ \\
\hline Datar & $0-5$ & $0-3$ \\
Landai & $5-15$ & $3-9$ \\
Agak terjal & $15-30$ & $9-17$ \\
Terjal & $30-50$ & $17-27$ \\
Sangat terjal & $50-70$ & $27-36$ \\
Tegak & $>70$ & $36-90$ \\
\hline
\end{tabular}

an Struktural Terjal mencakup sekitar 35\% dari seluruh lokasi penelitian. Berdasarkan kondisi mofologinya satuan ini dicirikan dengan kontur yang rapat pada peta topografi dengan kemiringan lereng sebesar $17^{\circ}-27^{\circ}$ (Nichols and Edmundson, 1975) dan ketinggiannya berkisar antara 500 - 662,5 mdpl. Satuan Bentuklahan Vulkanik Bergelombang Landai mencakup sekitar 65\% dari seluruh lokasi penelitian yang meliputi Desa Jatimekar dan Desa Mandalasari. Dari pengamatan di lapangan litologi yang ditemukan terdiri dari breksi laharik dan batupasir kerikilan. Satuan ini dicirikan oleh kontur yang relatif renggang pada peta topografi dengan kemiringan lereng sebesar $3^{\circ}-9^{\circ}$ dan ketinggianya berkisar antara 437,5 - 475 mdpl.

\section{Struktur Geologi}

Hasil pengamatan morfologi di lapangan menunjukkan bahwa faktor pengontrol yang bekerja di lokasi penelitian adalah struktur geologi. Berdasarkan hasil pemetaan pada lokasi penelitian ditemukan struktur berupa kekar dan indikasi lipatan. Struktur kekar pada umumnya ditemukan pada prselingan batupasir- batulempung. Struktur lipatan pada lokasi penelitian diindikasikan dari bidang perlapisan batuan yang relatif curam dengan kemiringan sekitar $40^{\circ}-75^{\circ}$, pada perselingan batupasir dan batulempung dan dijumpai pembalikkan arah dip.

\section{Kondisi Geologi Teknik Lokasi Penelitian}

Sifat fisik dan keteknikan tanah/ batuan, lokasi penelitian terbagi menjadi 4 satuan yang meliputi perselingan batupasir-batulempung, breksi laharik, batupasir kerikilan dan lanau lempungan (Gambar 3). Perselingan batupasir-batulempung mencakup sekitar $25 \%$ dari seluruh lokasi penelitian. Batulempung memiliki karakteristik berwarna abu-abu, tingkat pelapukan sedang, kekuatan batuan termasuk menengah. Pada satuan ini dilakukan pengujian sifat mekanik yaitu pengujian Unconfined Compression Test (UCS) dan diperoleh nilai kuat tekan $7,32 \mathrm{~kg} /$ $\mathrm{cm}^{2}$. Berdasarkan hasil pengukuran RMR (Rock Mass Rating) termasuk kelas II atau good rock.

Satuan breksi laharik mencakup sekitar $30 \%$ dari seluruh lokasi penelitian, karakteristik dari breksi laharik adalah berwarna abu-abu, struktur masif, tingkat pelapukan sedang, kekuatan batuan termasuk kuat (strong rock), pada satuan ini dilakukan pengujian sifat fisik meliputi kadar air sebesar $1,66 \%$, berat isi $27 \mathrm{kN} / \mathrm{m}^{2}$, porositas $31,49 \%$, dan void ratio 0,46 , berdasarkan pengujian point load diperoleh nilai kuat tekan sebesar $553,92 \mathrm{~kg} / \mathrm{cm}^{2}$. Berdasarkan pengukuran RMR termasuk kelas I very good rock.

Satuan batupasir kerikilan mencakup sekitar $10 \%$ dari seluruh lokasi penelitian, litologi tersebut memiliki karakteristik berwarna cokelat kekuningan, struktur gradasi normal, tingkat pelapukan sedang, kekuatan batuan menengah (medium strong rock). Pada satuan ini dilakukan 


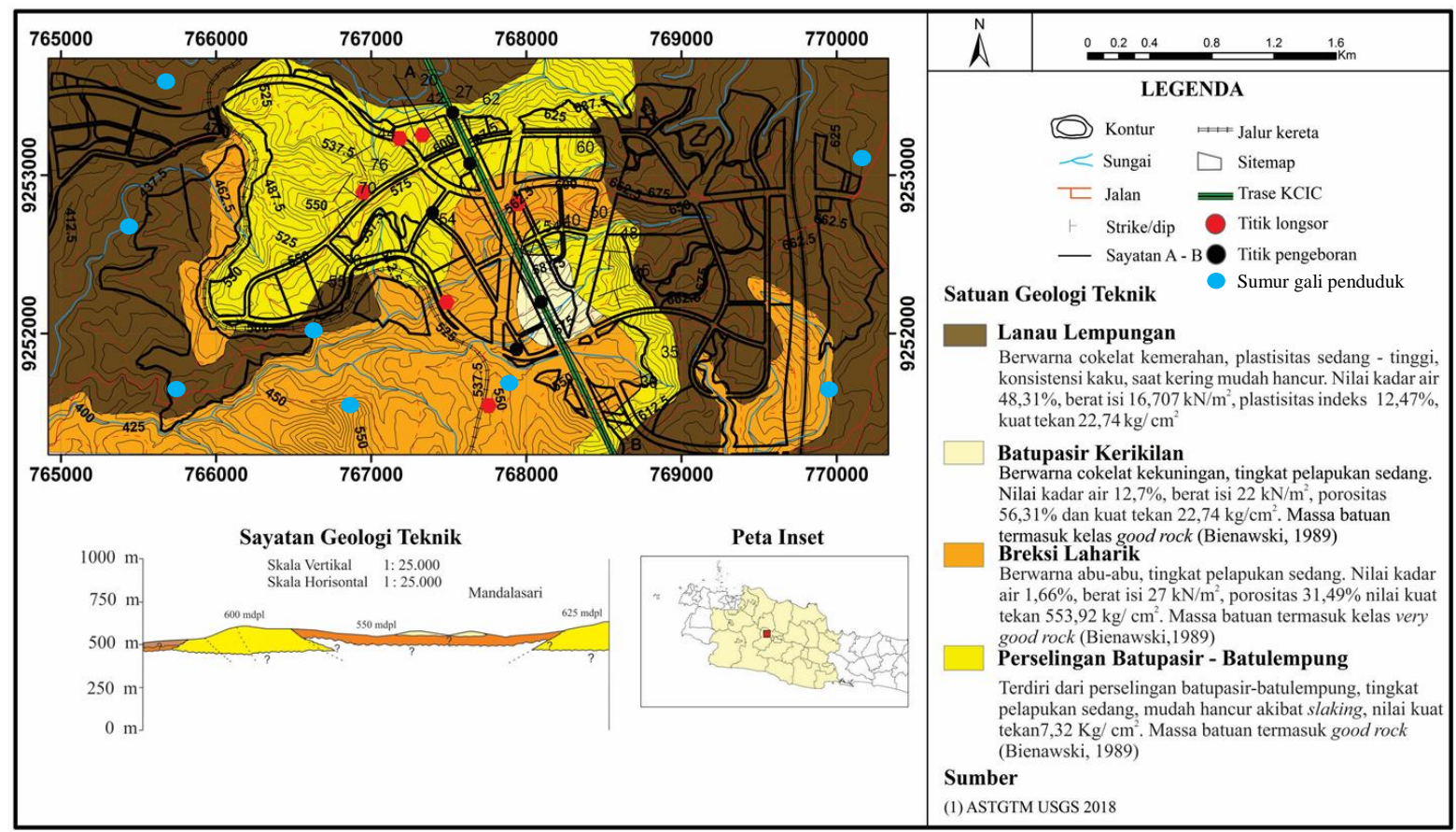

Gambar 3. Peta geologi teknik Daerah Walini dan sekitarnya.

pengujian sifat fisik meliputi kadar air sebesar $12,7 \%$, berat isi $22 \mathrm{kN} / \mathrm{m}^{2}$, porositas $56,31 \%$, dan void ratio 1,29 selain itu dilakukan pengujian $U C S$ dan diperoleh nilai kuat tekan $22,74 \mathrm{~kg} / \mathrm{cm}^{2}$. Berdasarkan hasil pengukuran RMR termasuk kelas II good rock (Tabel 2).

Satuan lanau lempungan terdiri tanah lanau lempungan dan lanau pasiran yang mencakup sekitar 35\% dari seluruh lokasi penelitian. Lanau lempungan memiliki karakteristik berwarna merah kecokelatan, plastisitas sedang - tinggi, umumnya tanah dalam kondisi lembab dan basah, konsistensi tanah kaku, dalam kondisi kering tanah mudah hancur, pada beberapa titik terdapat fragmen andesit dengan ukuran berangkal bongkah. Tanah lanau pasiran memiliki karakteristik berwarna cokelat kekuningan, konsistensi kaku, plastisitas rendah - non plastis, lembab, ukuran butir pasir sedang - kasar. Tanah lanau lempungan terletak di atas lanau pasiran. Berdasarkan karakteristiknya tanah lanau lempungan-lanau pasiran merupakan tanah residual hasil lapukan breksi laharik.

\section{Kedalaman Muka Air Tanah}

pada umumnya muka air tanah pada lokasi penelitian memiliki kedalaman sekitar 5-20 m. Pengukuran tersebut perlu dilakukan, karena kedalaman muka air tanah dapat mempengaruhi perencanaan fondasi bangunan, selain itu air tanah dangkal akan menggangu pengerjaan galian karena menyebabkan tanah/ batuan menjadi tidak stabil sehingga perlu dilakukan metode pengeringan dan membutuhkan biaya.

Pada analisis kemampuan geologi teknik, Utami dan Sutarjan (2000) mengklasifikasikan kedalaman muka air tanah menjadi 3 meliputi muka air tanah dangkal, menengah untuk mengetahui kemudahan dalam pengerjaan fondasi bangunan ringan. Muka air tanah pada lokasi penelitian rata-rata $>3 \mathrm{~m}$ sehingga termasuk air tanah dalam.

\section{Potensi Bencana Geologi}

Potensi bahaya geologi perlu dipertimbangkan pada perencanaan pengembangan kota baru di Walini, karena berkaitan dengan keselamatan penduduk yang akan menempati lokasi tersebut. a. Gerakan Tanah

Berdasarkan Peta Kerentanan Gerakan Tanah (PVMBG, 2008) lokasi penelitian terbagi menjadi 3 zona kerentanan gerakan tanah yaitu rendah, menengah dan sedang (Gambar4). Pada lokasi penelitian ditemukan titik longsor sebagian besar di daerah dengan litologi berupa perselingan batupasir-batulempung dan pada lereng yang material penyusunnya berupa tanah lanau lempungan. Longsoran pada lokasi penelitian termasuk jenis rotasi dimana pergerakan massa tanah dan batuan terjadi berupa 


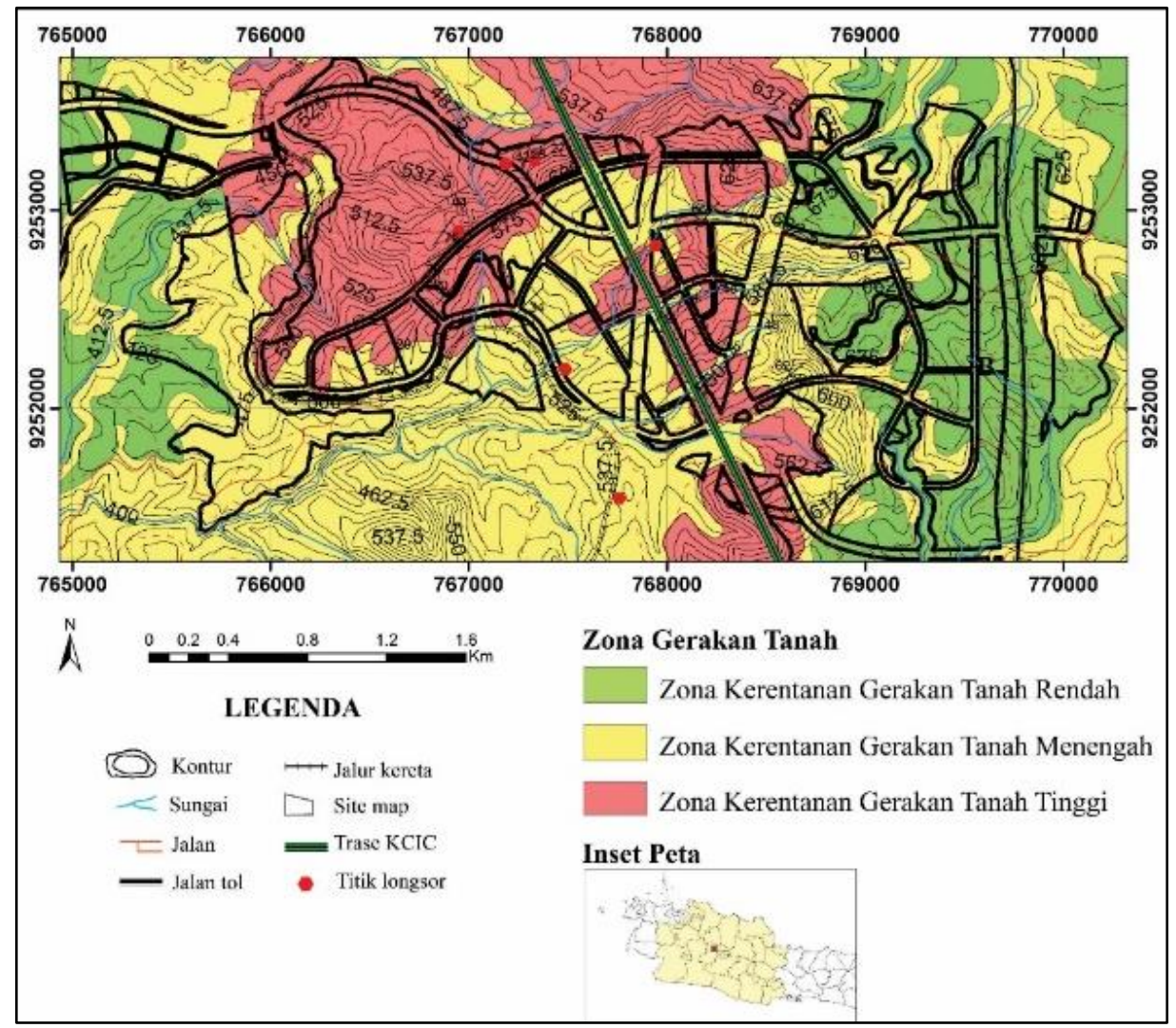

Gambar 4. Peta kerentanan gerakan tanah pada lokasi penelitian (PVMBG, 2008)

bidang gelincir berbentuk cekung. Mekanisme gerakan tanah yang terjadi pada tanah maupun batuan di lokasi penelitian diinterpretasikan terjadi karena adanya peningkatan air pada saat musim penghujan, air tersebut meresap melalui pori-pori dan rekahan pada tanah/ batuan, karena pada kedalaman tertentu terdapat lapisan batuan yang keras maka infiltrasi air tidak dapat berlanjut sehingga akan menjadi zona jenuh yang membentuk bidang gelincir dan mengakibatkan terjadinya gerakan tanah.

\section{b. Gempa Bumi}

Gempa bumi merupakan salah satu potensi bahaya geologi yang dapat terjadi di lokasi penelitian yang dapat menimbulkan berbagai dampak terhadap bangunan akibat percepatan gelombang seismik dan dapat mengakibatkan longsor. Besarnya dampak gempa bumi terhadap bangunan bergantung pada skala gempa, jarak episenter, mekanisme sumber, jenis lapisan tanah di lokasi bangunan dan kualitas bangunan. Berdasarkan SNI (2012) tentang standar perencanaan ketahanan gempa untuk struktur bangunan gedung dan non gedung, pengaruh gempa rencana harus ditinjau dalam perencanaan dan evaluasi struktur bangunan, yang ditetapkan dengan kemungkinan terlewati selama umur struktur bangunan 50 tahun adalah $2 \%$ (periode ulang 25.000 tahun), merujuk pada Peta Zonasi Sumber Gempa Indonesia (SNI, 2017) percepatan gempa bumi pada lokasi penelitian termasuk cukup tinggi yaitu dapat mencapai 0,4 $-0,5 \mathrm{~g}$, sehingga perlu dilakukan perencanaan desain kontruksi bangunan yang lebih resisten terhadap gempa.

\section{c. Bahaya Letusan Gunung Api}

Bahaya letusan gunung api yang dapat menimbulkan efek secara langsung terhadap penduduk antara lain gas-gas vulkanik, aliran lava, jatuhan piroklastik, lahar, abu vulkanik dan awan panas. Gunung api yang paling dekat dengan lokasi penelitian adalah gunung Tangkuban Perahu yang berjarak sekitar $42 \mathrm{~km}$. Berdasarkan peta zonasi kerawanan bencana gunung api Tangkuban Perahu lokasi penelitian berada pada zona aman.

\section{d. Banjir}

Banjir merupakan salah satu bencana yang sering terjadi terutama pada musim penghujan. 
Berdasarkan Peta Perkiraan Potensi Banjir (BMKG, 2018), lokasi penelitian termasuk daerah dengan tingkat kerentanan terhadap banjir yang rendah. Hal tersebut dipengaruhi oleh elevasi pada lokasi penelitian yang berada di dataran tinggi dengan elevasi sekitar $400-625$ mdpl dan merupakan area perkebunan dengan vegetasi yang relatif banyak sehingga mampu meningkatkan infiltrasi air tanah dan mengurangi aliran permukaan yang berupa banjir.

Pada penelitian ini re-evaluasi penggunaan lahan dilakukan berdasarkan peta kemampuan geologi teknik dengan menggunakan parameter yang meliputi kondisi geologi teknik untuk menahan fondasi bangunan, kemiringan lereng, pengerjaan penggalian tanah, tutupan lahan (Gambar 5) untuk mengetahui kemudahan persiapan pengerjaan, dan bahaya beraspek geologi. Pada penyusunan peta kemampuan geologi teknik parameter tersebut dilakukan pembobotan yang ditunjukkan pada Tabel 3 .

Interval kelas kemampuan geologi teknik di daerah penelitian ditentukan berdasarkan persamaan (1) dan diperoleh zonasi kemampuan geologi teknik dengan interval yang ditunjukkan pada Tabel 4 dan hasil peta ditunjukkan pada Gambar 6.

Tabel 2. Pembobotan parameter geologi teknik pada lokasi penelitian

\begin{tabular}{|c|c|c|c|c|}
\hline No & $\begin{array}{c}\text { Satuan Geologi } \\
\text { Teknik }\end{array}$ & Parameter & Nilai & Bobo \\
\hline \multirow[t]{8}{*}{1} & \multirow{8}{*}{$\begin{array}{l}\text { Perselingan } \\
\text { batupasir- } \\
\text { batulempung }\end{array}$} & Kuat tekan batuan utuh & $0,718 \mathrm{MPa}$ & 0 \\
\hline & & RQD & $69,12 \%$ & 13 \\
\hline & & Jarak diskontinuitas & $60-180 \mathrm{~mm}$ & 8 \\
\hline & & Kekasaran & Sedang & \\
\hline & & Separasi & $<1 \mathrm{~mm}$ & 25 \\
\hline & & Tingkat pelapukan & Sedang & \\
\hline & & Airtanah & Kering & 15 \\
\hline & & RMR & & 61 \\
\hline \multirow[t]{8}{*}{2} & \multirow[t]{8}{*}{ Breksi laharik } & Kuat tekan batuan utuh & $54,3209 \mathrm{MPa}$ & 15 \\
\hline & & RQD & $88,96 \%$ & 17 \\
\hline & & Jarak diskontinuitas & $200-600 \mathrm{~mm}$ & 10 \\
\hline & & Kekasaran & Sedang & \\
\hline & & Separasi & $<1 \mathrm{~mm}$ & 25 \\
\hline & & Tingkat pelapukan & Sedang & \\
\hline & & Airtanah & Kering & 15 \\
\hline & & RMR & & 82 \\
\hline \multirow[t]{8}{*}{3} & \multirow[t]{8}{*}{ Batupasir kerikilan } & Kuat tekan batuan utuh & 2,2298 MPa & 1 \\
\hline & & RQD & $90,9 \%$ & 17 \\
\hline & & Jarak diskontinuitas & $0,6-2 \mathrm{~m}$ & 15 \\
\hline & & Kekasaran & Sedang & 25 \\
\hline & & Separasi & $1 \mathrm{~mm}$ & 25 \\
\hline & & Tingkat pelapukan & Sedang & \\
\hline & & Airtanah & Kering & 15 \\
\hline & & RMR & & 73 \\
\hline
\end{tabular}


Tabel 3. Pembobotan parameter geologi teknik pada lokasi penelitian

\begin{tabular}{|c|c|c|c|c|c|}
\hline Parameter & Klasifikasi & Kelas & Nilai & Bobot & Skor \\
\hline \multirow{3}{*}{$\begin{array}{l}\text { Kemampuan satuan } \\
\text { tanah/ batuan untuk } \\
\text { menahan fondasi } \\
\text { bangunan }\end{array}$} & Breksi laharik & Tinggi & 4 & 5 & 20 \\
\hline & $\begin{array}{l}\text { Batupasir kerikilan, perselingan } \\
\text { batupasir - batulempung }\end{array}$ & Menengah & 3 & & 15 \\
\hline & Lanau lempungan & Rendah & 2 & & 10 \\
\hline \multirow{3}{*}{$\begin{array}{l}\text { Kemudahan } \\
\text { pengerjaan } \\
\text { penggalian }\end{array}$} & $\begin{array}{l}\text { Mudah (lanau lempungan - lempung } \\
\text { pasiran) }\end{array}$ & Tinggi & 4 & 3 & 12 \\
\hline & $\begin{array}{l}\text { Sukar (batupasir kerikilan, perselingan } \\
\text { batupasir - batulempung) }\end{array}$ & Rendah & 2 & & 6 \\
\hline & Sangat sukar (breksi laharik) & $\begin{array}{l}\text { Sangat } \\
\text { rendah }\end{array}$ & 1 & & 3 \\
\hline \multirow[t]{2}{*}{ Kemiringan lereng } & $3-9^{\circ}$ & Tinggi & 3 & 5 & 15 \\
\hline & $17-27^{\circ}$ & Menengah & 2 & & 10 \\
\hline \multirow{4}{*}{$\begin{array}{l}\text { Kemudahan } \\
\text { pengerjaan } \\
\text { (berdasarkan } \\
\text { tutupan lahan) }\end{array}$} & Pemukiman & Tinggi & 4 & 2 & 8 \\
\hline & Sawah & Menengah & 3 & & 6 \\
\hline & Perkebunan & Rendah & 2 & & 4 \\
\hline & Perkebunan & $\begin{array}{l}\text { Sangat } \\
\text { rendah }\end{array}$ & 1 & & 2 \\
\hline \multirow{8}{*}{$\begin{array}{l}\text { Bahaya beraspek } \\
\text { geologi }\end{array}$} & Rawan longsor & & & & \\
\hline & Rendah & Tinggi & 3 & 5 & 15 \\
\hline & Menengah & Menengah & 2 & & 10 \\
\hline & Tinggi & Rendah & 1 & & 5 \\
\hline & Kerentanan gempa & & & & \\
\hline & $0,4-0,5 \mathrm{~g}$ & Rendah & 1 & 5 & 5 \\
\hline & $\begin{array}{l}\text { Kerentanan banjir } \\
\text { Aman }\end{array}$ & Tinggi & 4 & 4 & 16 \\
\hline & $\begin{array}{l}\text { Kerentanan gunung api } \\
\text { Aman }\end{array}$ & Tinggi & 4 & 5 & 20 \\
\hline
\end{tabular}

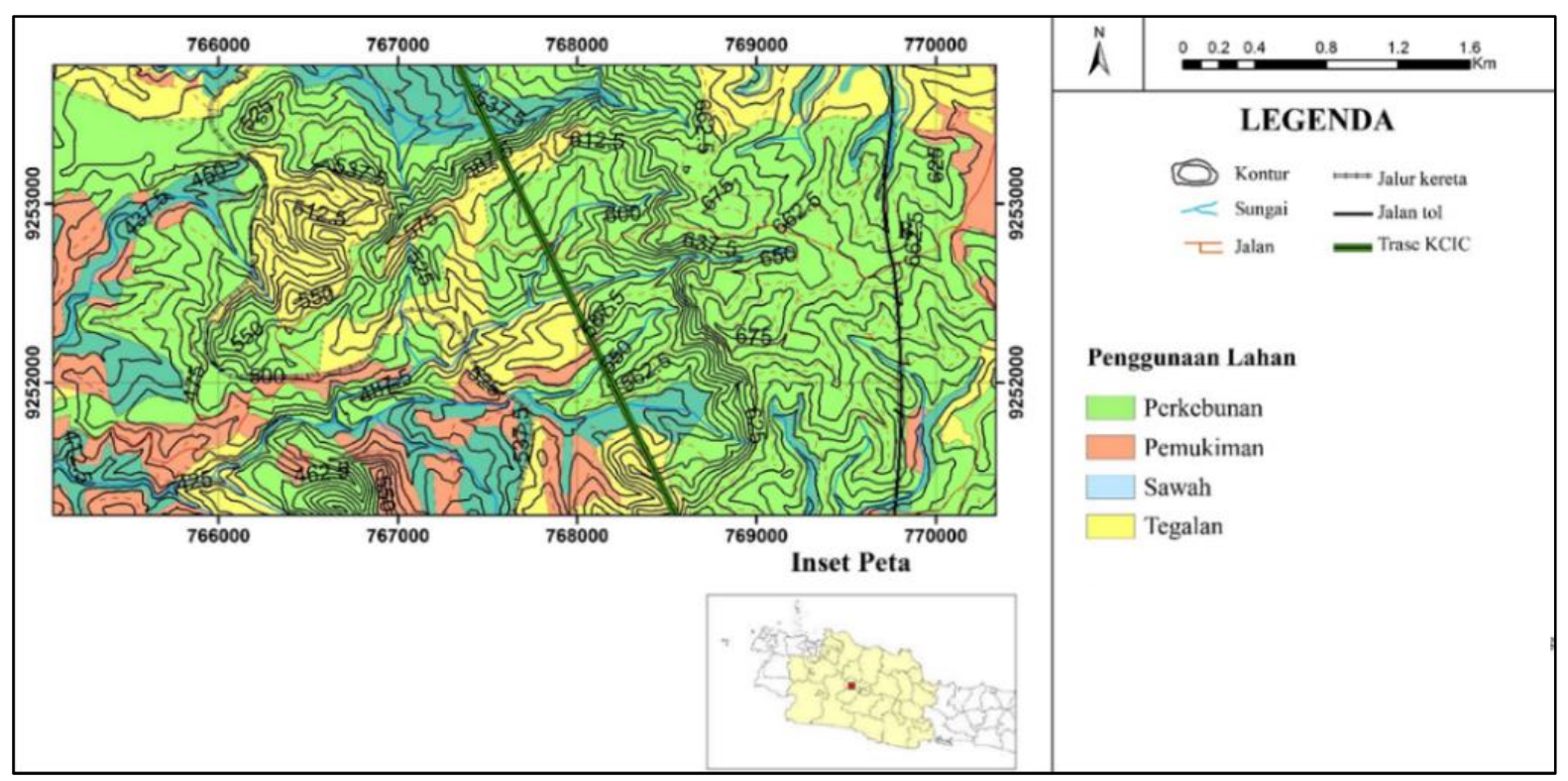

Gambar 5. Peta tutupan lahan pada lokasi penelitian (BAKOSURTANAL, 2007) 


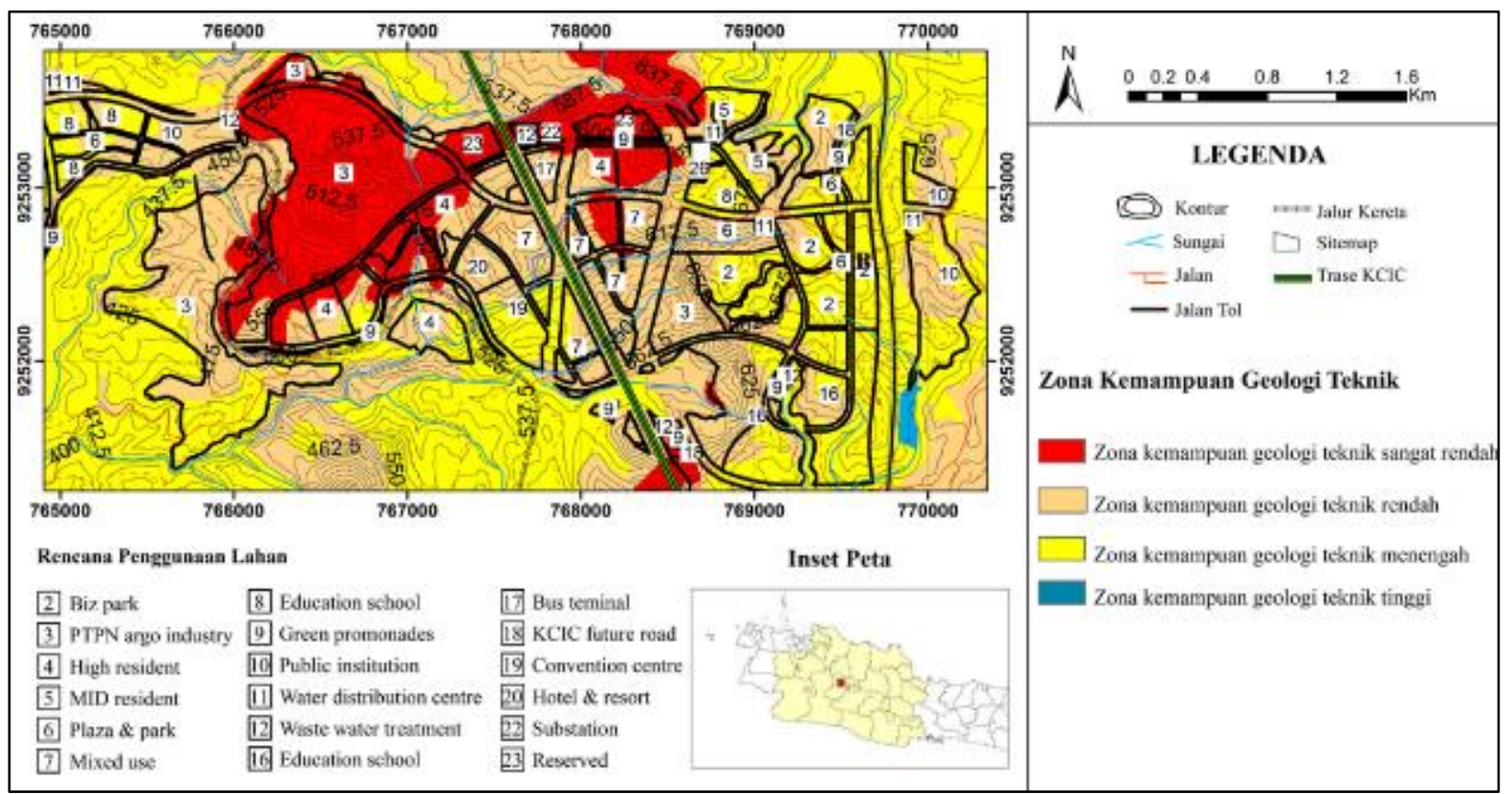

Gambar 6. Peta kemampuan geologi teknik Daerah Walini dan sekitarnya.

Tabel 4. Interval kemampuan geologi teknik pada lokasi penelitian

\begin{tabular}{cc}
\hline Skor & $\begin{array}{c}\text { Zona kemampuan geologi } \\
\text { teknik }\end{array}$ \\
\hline$<84$ & Sangat rendah \\
$84-94$ & Rendah \\
$94-104$ & Menengah \\
$>104$ & Tinggi \\
\hline
\end{tabular}

\section{a. Zona Kemampuan Geologi Teknik Sangat Rendah}

Zona kemampuan geologi teknik sangat rendah mencakup 25\% dari seluruh peta lokasi penelitian. Rencana penggunaan lahan pada wilayah ini adalah sebagai PTPN argo industry, high resident, green promonades, waste water treatment, substanstion dan reserved.

Area ini memiliki kemiringan lereng $17^{0}$ $27^{0}$, kemiringan lereng tersebut dinilai cukup tinggi dan berdampak pada tingginya potensi gerakan tanah. Satuan geologi teknik penyusun daerah ini terdiri dari perselingan batupasirbatulempung dengan kekuatan batuan sedang untuk dijadikan sebagai dasar fondasi dan relatif keras untuk dilakukan penggalian sehingga diperlukan biaya yang tinggi untuk melakukan pekerjaan konstruksi, penggunaan lahan pada area tersebut berupa perkebunan dengan akses jalan yang masih sedikit dapat menyebabkan persiapan pengerjaan proyek menjadi terkendala sehingga memerlukan biaya yang tinggi.

\section{b. Zona Kemampuan Geologi Teknik Rendah}

Zona kemampuan geologi teknik rendah mencakup sekitar $30 \%$ dari seluruh lokasi penelitian. Rencana penggunaan lahan pada zona ini adalah sebagai bizpark, PTPN argo industry, high resident, plaza \& park, mixed use, green promenade, hotel \& resort, waste distribution centre, waste water treatment dan KCIC future road.

Area ini dominan memiliki kemiringan lereng terjal yaitu $17^{0}-27^{0}$ dan tingkat kerentanan gerakan tanah pada area ini menengah - tinggi maka kemampuan geologi tekniknya relatif rendah. Batuan penyusun pada lokasi ini berupa perselingan batupasir-batulempung, batupasir kerikilan dan breksi laharik yang memiliki kemampuan sebagai dasar fondasi menengah tinggi dan relatif sulit dilakukan penggalian sehingga memerlukan biaya yang relatif tinggi untuk pengerjaan konstruksi. Penggunaan lahan pada area ini berupa tegalan dan perkebunan sehingga akses untuk menjangkau lokasi lebih mudah untuk persiapan pengerjaan konstruksi namun tetap memerlukan biaya cukup tinggi.

\section{c. Zona Kemampuan Geologi Teknik Menengah \\ Zona kemampuan geologi teknik} menengah mencakup $40 \%$ dari seluruh lokasi penelitian. Berdasarkan perencanaan yang telah dilakukan pada lahan ini akan dikembangkan 
menjadi biz park, mid resident, plaza \& park, education school, dan public Institution.

Area ini memiliki kelerengan sekitar $3^{0}-9^{0}$, dengan tingkat kerentanan gerakan tanah rendah - menengah sehingga relatif aman untuk dilakukan pembangunan. satuan geologi teknik penyusun daerah ini terdiri dari lanau lempunganlanau pasiran, batupasir kerikilan, dan breksi laharik. Area ini dekat dengan pemukiman sehingga cukup mudah untuk melakukan persiapan pekerjaan konstruksi, karena sebagian batuan penyusunya adalah breksi laharik yang sangat sukar untuk dilakukan penggalian maka tetap memerlukan biaya untuk pengerjaannya, namun biaya yang dibutuhkan relatif rendah jika dibandingkan pada zona kemampuan geologi teknik rendah dan sangat rendah.

\section{d. Zona Kemampuan Geologi Teknik Tinggi}

Pada lokasi penelitian zona kemampuan geologi teknik tinggi hanya mencakup sekitar 5\% dari seluruh lokasi penelitian. Area tidak termasuk kedalam rencana pengembangan yang dilakukan oleh PT. KCIC. kemiringan lereng pada area ini sekitar $3^{0}-9^{0}$, dengan tingkat kerentanan gerakan tanah rendah sehingga kemampuan geologi tekniknya tinggi dan sesuai jika akan dilakukan pembangunan pada area ini. Satuan geologi teknik pada zona ini berupa breksi laharik yang memiliki kekuatan batuan yang tinggi untuk dijadikan sebagai fondasi bangunan. Lahan pada area ini di gunakan sebagai pemukiman sehingga persiapan pengerjaan konstruksi akan lebih mudah dan memerlukan biaya yang rendah untuk pengerjaanya.

\section{KESIMPULAN}

Daerah Walini, Kecamatan Cikalong Wetan, Kabupaten Bandung Barat, Provinsi Jawa Barat memiliki : (1) dua satuan geomorfologi yaitu bentuklahan perbukitan struktural terjal dan bentuklahan perbukitan vulkanik bergelombang landai; (2) empat satuan litologi terdiri dari satuan batupasir-batulempung, breksi laharik dan batupasir kerikilan ; dan (3) satuan geologi teknik yang terdiri dari perselingan batupasirbatulempung yang mencakup sekitar $25 \%$ dari seluruh lokasi penelitian kekuatan batuan menengah, tingkat pelapukan sedang, berdasarkan pengukuran RMR termasuk good rock, breksi laharik mencakup sekitar $30 \%$ dari lokasi penelitian, kekuatan batuan menengah, tingkat pelapukan sedang, berdasarkan pengukuran RMR termasuk very good rock, batupasir kerikilan $10 \%$ dari seluruh lokasi penelitian berdasarkan pengukuran RMR termasuk kelas good rock dan lanau lempungan mencakup $35 \%$ dari seluruh lokasi penelitian dengan karakteristik plastisitas sedang - tinggi, lembab dan konsistensi kaku. Daerah penelitian dibagi menjadi 4 zona yaitu zona kemampuan geologi sangat rendah, zona kemampuan geologi teknik rendah, zona kemampuan geologi teknik menengah dan zona kemampuan geologi teknik tinggi.

\section{UCAPAN TERIMAKASIH}

Terimakasih saya ucapkan kepada Badan Geologi Bandung yang telah memberikan kesempatan untuk melakukan pengambilan data.

\section{DAFTAR PUSTAKA}

Bakosurtanal, 2007. Peta Provinsi Jawa Barat skala 1:1.000.000. Badan Koordinasi Survai dan Pemetaan Nasional: Bogor

BMKG, 2018. Peta perkiraan daerah potensi banjir di Jawa Barat. Badan Meteorologi, Klimatologi, dan Geofisika.

Khadiyanto, P., 2005. Tata Ruang Berbasis pada Kesesuaian Lahan. Badan Penerbit UNDIP: Semarang.

Martodjojo, S. 1984. Evolusi Cekungan Bogor, Jawa Barat. Disertasi. Institut Teknologi Bandung: Bandung.

Masri, R.M., 2012. Analisis Keruangan Kesesuaian Lahan untuk Pemukiman di Kabupaten Bandung dan Bandung Barat. Forum Geografi, Vol.26, No.2, Hal.190 201.

Nichols, D.R. dan Edmundson., 1975. Text to Slope Map of Part of West Central King Country. United States Geological Survey Miscellaneous Geologic Investigations Map, $I-825-E$.

PVMBG, 2008a. Peta Kerentanan Gerakan Tanah Kabupaten Bandung Barat.

PVMBG, 2008b. Peta Rawan Bencana Gunung Api Tangkuban Perahu.

SNI, 2012. Tata Cara Perencanaan Ketahanan Gempa untuk Struktur Bangunan Gedung dan Non Gedung. Badan Standarisasi Nasional: Jakarta.

SNI, 2017. Peta Sumber dan Bahaya Gempa Indonesia Tahun 2017. Pusat Penelitian dan Pengembangan Perumahan dan Pemukiman: Bandung. 
Sudjatmiko, 1972. Peta Geologi Lembar Cianjur, Jawa skala 1:100.000. Pusat Penelitian dan Pengembangan Geologi: Bandung.

The Unesco Press, 1976. Engineering Geological Maps: A guide to their preparation. Unesco: Paris.

Utami, T. E. dan Sutarjan, W., 2000. Rancangan aplikasi SIG untuk pembuatan peta zona kemampuan geologi teknik: Studi kasus daerah Jember skala 1:100.000. Buletin Geologi Tata Lingkungan (Bulletin of Environmental Geology) vol. 11, No.4, hal $179-184$.

van Bemmelen, R. W., 1949. Geology of Indonesia. Vol. IA. Government Printing Office, The Hague. 